Journal of Teacher Education for Sustainability, vol. 19, no. 1, pp. 54-68, 2017

\title{
Teacher Job Dissatisfaction: Implications for Teacher Sustainability and Social Transformation
}

\author{
Chinedu I. Okeke \\ Faculty of Education, University of Fort Hare, South Africa \\ Pamela N. Mtyuda \\ Queenstown Education District, South Africa
}

\begin{abstract}
Teachers play a key role in the social transformation agenda. This agentic position of the teacher implicates an agenda for sustainability programmes that position them for this complex responsibility. A qualitative case study research design was employed to obtain the perspectives of teachers on job dissatisfaction. The researchers followed a semi-structured interview approach to explore teachers' broader understanding on causes of job dissatisfaction among them. Data was interpreted through the narrative analysis model. Results indicate that a lack of resources, overcrowded classes and lack of discipline among learners were serious sources of dissatisfaction among teachers. Administrative issues, lack of recognition by principals and parents for good work done also caused dissatisfaction among teachers in this study. It was also indicative that job dissatisfaction caused disengagement of some teachers with a consequent lack of focus on professional activities and being negative in their job. The study concludes that teacher satisfaction is germane for the sustainability of social transformation.
\end{abstract}

Keywords: Agency, dissatisfaction, education, teacher sustainability, transformation.

Research shows that workers who feel undervalued and unappreciated may consider leaving their jobs for something else (Calitz, Roux, \& Strydom, 2014). The job satisfaction of teachers, particularly at secondary school level, is vital. The value of secondary education is equally undeniable. It is very important to provide teachers with the facilities so that they must be satisfied with the status of their job. Better performance of teachers can only be expected if they are satisfied with their jobs.

The researchers informally observed the course of numerous school visits, on-site monitoring and support visits, examination of school documents, schools records, attendance registers and leave record books that every week at least 3 teachers handed in. There were also red lines drawn against names of teachers in the attendance registers indicating absence from school or late coming to school. A common complaint among teachers was that their job security was not guaranteed these days. Many new teachers were employed on a temporary basis. Some of them had been placed on the list of 
temporary teachers for as long as ten years at the time of this study. Promotions are rare; one can enter as post level one teacher and go into retirement, about 25 years later, and still be a post level one teacher. Given the above situation, the current study investigated the teachers' perspectives on the causes of job dissatisfaction among senior secondary school teachers in one Eastern Cape Education District.

\section{Maslow's Hierarchy of Needs}

Maslow's hierarchy of human needs is one of the motivational theories associated with Abraham Maslow in 1943 (Peretomode, 1991; Spector, 2008). The theory is also a content theory of motivation, which focuses on the factors within persons that start, energize, direct, maintain and stop behaviour. It can motivate or discourage human behaviour in the sense that its positive influence causes satisfaction, while its negative influence causes dissatisfaction and causes one to react either positively or negatively. Maslow postulated five basic human needs, including physiological, safety and social needs as well as higher needs: ego or esteem need and self-actualisation. Physiological needs consist of the need for basic biological needs, which include the need for food, water, air, sexual gratification and other primary needs such as shelter, clothing, etc. When the physiological needs are not satisfied, no other need will serve as a basis for motivation (Maslow, 1954; Spector, 2008).

Once physiological needs are satisfied, then newer needs emerge. In the school system, the salary one earns enables him or her to satisfy these needs but if the needs go unfulfilled it results in dissatisfaction, which affects productivity and quality performance at work. Safety needs emerge once the physiological needs are achieved. This includes the need for security, safety, protection against danger and accidents (threats, deprivation, psychological harm, economic disaster) and stability in the physical and internal events of day-to-day life. School teachers are willing to have the feeling that their job and accommodation is secured When such confidence is lacking, it threatens their performance and work commitment (Perrachione, Rosser, \& Petersen, 2008). While almost all teachers work hard in order to satisfy their needs, they constantly struggle to meet their various needs.

\section{Teacher Wellbeing in the Context of Sustainability}

Teacher wellbeing is pivotal for achieving a well-sustained social transformation that is greatly required within the South African educational institutions and larger society. However, where the wellbeing of teachers is relegated, a situation may arise in which a key agent for achieving sustainable social transformation may be ill-prepared to partake in such a process. According to Wensing and Torre $(2009,5)$, if we are to achieve sustainability "teachers and school boards must collectively adopt a broader scope of education and action... one that is both informational and transformational". To achieve these objectives requires that teachers constantly engage in self-action research that is implemented in order to gain new experience as well as improve wellbeing.

Research plays an important role in revealing the everyday understanding of the teachers' psychosocial, intellectual as well as material needs; the outcome of which will conflate into improvement of the teachers' wellbeing. That is why Tillmanns, Holland, 
Lorenzi and McDonagh (2014: 5) suggest that "empowering teachers to reframe mindsets, particularly those that result in unsustainable behaviours and/or actions”, may be central to achieving teacher sustainability necessary for social transformation. However, it should be noted as earlier argued by Lukk, Veisson and Ots (2008: 36) that the success of sustainable transformation through any form of education "will ultimately depend on the decisions individuals and groups make regarding their own behaviour and the bottom-line of these decisions is their value systems.

As functional education is a key to teacher sustainability and social transformation, continuing professional teacher development that impacts their wellbeing should not only target the academic dimension; such a programme should also be geared towards empowering teachers to engage in the self-study. Such self-intuition is necessary since it enables the teacher to actively engage in those activities that will enable the improvement of behaviour necessary for sustainability (Wensing \& Torre, 2009). Therefore, Jonane (2015: 53) notes that "education for sustainable development requires new ways of conceiving goals, tasks, organisation of learning, and the teacher training”.

\section{Job Dissatisfaction}

Job dissatisfaction is by definition unpleasant, and most individuals are conditioned, probably even biologically-driven, to respond to unpleasant conditions by searching for mechanisms to reduce dissatisfaction (Okeke \& Dlamini, 2013; Afshar \& Doosti, 2016). This drive towards adaptation is as natural and inevitable in the workplace as it is in any other environment (Chan, 2002). Prior theory and research (Farrell, 2000) suggest that employees respond to job dissatisfaction in one of the four ways: exit, voice, loyalty and neglect.

Firstly, and consistent with the turnover literature (Farrell, 2000), dissatisfied employees may quit an organisation altogether in response to their job dissatisfaction (exit). Secondly, dissatisfied employees may choose to remain in their organisation and actively try to improve conditions, actively searching for and coming up with new ways of doing things also advocating changes to make things better (voice). Thirdly, employees may remain in the organisation but respond passively to their job dissatisfaction by accepting the status quo without raising any objections or making any suggestions for improvement (loyalty). Lastly, employees may remain in the organisation and exhibit passive withdrawal behaviours such as putting forth less effort (neglect) (Farrell, 2000; Muguongo et al. 2015; Wambugu \& Busienei, 2015).

\section{Causes of Teacher Job Dissatisfaction}

The retention of teachers has been a very challenging phenomenon, not only in the South African education system, but also in many different education systems across the globe (Naseem \& Salman, 2015). Dissatisfaction has been deduced by researchers as posing a major challenge for the retention of teachers and other workers (Calitz, Roux, \& Strydom, 2014). Such a scenario appears to threaten the agentive roles of teachers for sustainability and social transformation in schools and larger society. A study of 110 teachers in Abbottabad, Pakistan, by Naseem and Salman (2015) suggests that factors such as gender, education, marital status, relationship with the supervisor/ 
principal and co-workers as well as sense of job security are correlates of either satisfaction or dissatisfaction among the participants.

An effective teaching force is essential for the sustainability and social transformation of the society across countries. Gkolia, Belias and Koustelios (2014: 321) note that "teachers who are satisfied with their jobs usually have a high degree of professional capabilities and feel that they could manage, organise and perform task". In Zimbabwe, Adebayo and Gombakomba (2013) explored the dimensions of teacher job satisfaction from a sample of 161 primary school teachers. The study found out that "teachers were not paid adequate salary and that they were rarely provided with non-financial incentives" (Adebayo \& Gombakomba, 2013: 316). It is obvious from the study that the sustainability of teacher retention will almost be guaranteed in a climate where teacher job security, infrastructure and teaching resources as well as financial incentives are guaranteed.

Yet, studies have reported a relationship between the individual's psychosocial wellbeing and his/her job satisfaction or dissatisfaction levels. In Madrid and Almeria, Spain, 68 secondary school teachers from varying cultural background were sampled by Briones, Tabernero and Arenas (2010). The aim of their study was to establish the effects of several demographic and psychosocial factors involved in teachers' job satisfaction or otherwise. Results of the study revealed that "self-efficacy in teaching, perception of emotional exhaustion and personal achievement, as well as perceived support from colleagues and the head teacher play important role in teachers' job satisfaction" (Briones et al., 2010: 119). The authors concluded that those whose psychosocial wellbeing was negative would most certainly experience discontentment with respect to their approaches to their work commitments.

Within the South African context, many studies have identified various problem categories that can cause job dissatisfaction among teachers (van der Westhuizen, 2004; Adu \& Okeke, 2016; Afshar \& Doosti, 2016). It has been noted that the new democratic dispensation in the country has intermittently introduced changes in education, and in many instances principals and teachers have found it difficult to adapt to these changes (Masitsa, 2004). In addition, Smit (2002) notes that problems within the teachers are generally perceived as deficiencies or inadequacies, which exist within a person. Similarly, role conflict, stress, personal development, professional development, morale as well as personal and professional aims can all be seen as problems within a person that can be sources of dissatisfaction (Song \& Alpaslan, 2015; Adu \& Okeke, 2016; Gu, 2016).

Studies have also indicated that there are problems in the classroom that teachers have to contend with daily, which can be sources of job dissatisfaction among the affected teachers. Lack of textbooks, learners' discipline, class size, assessment, issues with HIV/AIDS, Whole-School Evaluation (WSE) and relationship with learners are the problems a teacher has to face within the classroom (Van Houtte, 2006; Okeke, Adu, Drake, \& Duku, 2014; Gu, 2016; Shumba, Maphosa, Rembe, Okeke, \& Drake, 2016 b). It should be noted that not all teachers are soundly equipped to deal with these problems.

One of the complex problems in the work environment of the teacher is the physical working conditions and the lack of physical facilities she or he has to cope with every day, especially subjects such as science and technology. Other problems in the work environment are related to factors within the work itself (van Houtte, 2006). It has also been noted that the values of a society can be viewed as problematic if a person's (i.e. 
teacher's) values differ from those of the society (van der Westhuizen, 2004). Problems in the community are related to parental involvement, the post 1994 political climate in South Africa and the socio-economic climate.

The level of provisioning in respect to education human resources is generally expressed in terms of a learner-teacher ratio. The allocation of funds by the South Africa's National Treasury to provinces is largely aimed at ensuring that a certain learnerteacher ratio applies in schools. However, learner-teacher ratios are often confused with class size whilst it is a fact that class sizes are generally considerably higher than the prevailing learner-teacher ratio. A class size is not only a function of how many learners go to school. It is also dependent on the number of physical infrastructure units, such as the capacity of the classrooms to accommodate teachers and the subjects on offer (DoE, 2005).

A study by French and Wagner (2010) has found out that children are taking turns to learn under trees and sometimes share the teachers' staffroom as a make-shift classroom. In other cases, two complete classes would be housed within one physical class building with both teachers teaching on opposite ends of the classroom. This erodes the semblance of quality teaching and learning that is supposed to have a bearing on the children. Given these scenarios, it is imperative to deal with issues of job dissatisfaction through an empirical study that is aimed at further exploring this particular phenomenon. By so doing, it was researchers' expectations that this paper would contribute towards knowledge that might facilitate the strengthening of teachers to enable them to continue their agentic roles towards sustainability and social transformation.

\section{Research Methodology}

\section{Design and Sample}

The qualitative case study research approach was followed because it sought to understand the teachers' perspectives on causes of job dissatisfaction among senior secondary school teachers in one Education District in the Eastern Cape Province. A case study is ideal when a holistic, in-depth investigation is required to understand a particular phenomenon or experience (Babbie, 2008; Okeke, 2010; Creswell, 2014). The target group was purposefully selected from schools that have a cosmopolitan staff composition with various race groups, gender and also teachers with varying years of teaching experience. The sample size for the study comprised of 12 senior secondary school teachers from the six Circuits in the participating Education District, 3 schools from the rural areas and 3 schools from the urban areas.

\section{Instrument and Data Analysis}

Semi-structured interview and the focus groups discussions were used to obtain information on participants' perceptions, opinions, beliefs and attitudes towards their jobs as teachers. Moreover, both instruments were carefully organised to enable the researchers to seek broader explanations on teachers' perspectives on causes of job dissatisfaction among senior secondary school teachers. The questions provided an opportunity for both the interviewers and the interviewees to discuss the topic as 
comprehensively as possible. Qualitative research often seeks to illuminate the ways individuals interact to sustain or change social situations. The researchers were personally involved in the process of data collection. With the permission of the participants, taperecording instrument was used in all the sessions of the data collection procedure.

The narrative analysis model (Taylor-Powell \& Renner, 2003) was adopted in the analysis of data obtained from the fieldwork. Taylor-Powell and Renner (2003) suggest that this model is relevant in analysing data obtained through individual interviews and the focus group discussion (MacMillan \& Schumacher, 2010). Within the narrative analysis framework, the researchers were able to transcribe, synthesise, organise, analyse and interpret the data. Synthesising and organising of data involved a coding process that allowed for data reduction in order to sieve data of impurities from the emerging themes and categories. Findings are presented descriptively.

\section{Ethical Considerations}

The researchers were ethically responsible for protecting the rights and welfare of the participants, which involved issues such as physical and mental $\mathrm{r}$. Ethical approval was obtained from the Research Ethics Committee at Fort Hare University and from the Department of Education in the Eastern Cape Province where the schools chosen for this study were situated. The researchers also wrote letters to the School Governing Boards (SGBs), Principals, Schools Management Teams (SMTs) and Head of Department at schools (HODs) asking and receiving permission to conduct the fieldwork.

All the information obtained in the study was treated confidentially. The participants were assured that the collection of data from the interviews was for academic purposes only and no information would be revealed that might result in embarrassment or direct negative consequences. A sense of caring and fairness was part of the researchers' thinking, actions and personal morality. The study therefore ensured that ethical and legal guidelines set by the national government were followed.

\section{Results}

\section{Views on Causes of Job Dissatisfaction}

Qualitative data confirmed general dissatisfaction with facilities to make teaching and learning easy, especially for practical lessons. For instance, findings showed that there were no resources at all for schools in the rural areas; teachers shared teaching resources with the other schools that had them. Findings also indicated that overcrowding in classrooms made it impossible for teachers to maintain discipline in their classrooms when dealing with adolescents. Discipline was a big problem on its own for all schools, especially for the combined high and primary schools.

\section{Forms of Intrinsic Motivators}

20 percent of the teachers confessed that they joined the teaching profession only as a source of income. One participant emphasised the joy of doing his work as a teacher as expected, so as to avoid stress while another participant said that his joy 
comes from working with his students. This study investigated various indicators of intrinsic motivators including job satisfaction derived from teaching; enjoyment of teaching; the challenging and competitive nature of teaching; recognition; career development; control over others; teaching as one's goal in life and usefulness to the community among others. To ensure teacher sustainability and retention, which enable them to continue to perform their agentic roles, it is imperative to understand various sources of teachers' intrinsic motivation.

\section{Forms of Extrinsic Motivators}

Teachers mentioned administrative issues - large class sizes, poor salaries. Although they were overworked they were underpaid compared to private sector employees. Lack of merit appointments to senior posts, inequality in teaching loads between management and staff were also mentioned. Data also revealed some relationship problems. For instance, participants complained about lack of unity amongst colleagues in 80 percent of the schools. There were also issues with professional jealousy and they were not recognised by their principals for good work done because of favouritism.

Findings suggested that the teacher participants also encountered student related problems - poor discipline, laziness, disrespect to teachers and school rules by students, students coming late to school, high absenteeism and absconding. Again, results indicated that teachers also emphasised the importance of the climate of the school, which provided a major setting for learners to develop new and different relationships with peers and teachers. On the academic instruction and curriculum the teachers complained that focus was administrative not holistic, only the maintenance of records and assessment tasks were time-consuming and impeded progress. On the other hand, there was a lack of professional development and a drop in pass rate requirements lowered the standard. On the other hand, teachers further complained about district officials who did not have enough knowledge to be able to help them.

\section{Teachers' Performance in Schools}

Results indicated that 89 percent of teachers came early to their schools; attendance registers in all the schools also confirmed this scenario. Results equally suggested that 98 percent of teachers did regular testing and feedback given to students. The exams analysed showed that either the students were lazy or teachers were not doing enough. Findings also suggested that teachers complained of too much of administrative work that they were faced with, although the introduction of CAPS (Curriculum Assessment Policy Statement) aimed at reducing too much administrative work for teachers. In addition, results suggested that only 39 percent of the teacher participants were efficient at disciplining students, while 61 percent feared for their lives due to a lack of security measures in place to protect them from radical students. Moreover, 84 percent of teachers supervised all school activities. Findings also indicated that 82 percent of teachers prepared lesson plans before going to class and the researchers were able to check on all that from the teachers' files. It was therefore thought that the performance of these teachers was average despite the fact that their motivation was inadequate. 


\section{Problems Encountered by Teachers in the Schools}

Lack of teachers in critical subjects in most senior secondary schools in the Education District was found in the study to be the major problem that had contributed to a high rate of failure in the Matric examination among students. Results were also indicative of the fact that most teachers who were deeply in debt had opted to resign so as to get money to pay off their debts. Currently, Eastern Cape features a hugely unbalanced distribution of teaching staff at the senior secondary school level.

\section{Aspirations to Become a Teacher}

Results suggested that 80 percent of teachers chose teaching to help young children to develop as responsible individuals in the society. Moreover, 89 percent of them had a passion for teaching their classmates whilst they were still students.

\section{Discussion}

\section{Views on Causes of Dissatisfaction}

General dissatisfaction was expressed with regard to their physical working conditions. The data obtained by means of semi-structured open-ended questions confirmed that previously disadvantaged schools experienced problems with infrastructure that hampered the delivery of quality public education. The teachers referred to poor facilities, absence of maintenance, serious water shortage, and poor roads leading to the rural schools. It was mentioned that the roads were particularly bad when it rained. They also referred to electricity problems and the unkempt school environments. The surroundings included dilapidated buildings, tall grass and overgrown shrubs that made the schools look uninviting.

Earlier studies (Okeke \& Dlamini, 2013; Dlamini et al., 2014; Afshar \& Doosti, 2016), pointed out that positive work environment was very important for the workers' physical, mental and emotional health. According to Khan (2003), favourable working conditions would boost teachers' job satisfaction. Iwu and Iwu (2013) observed that a lack of adequate infrastructure was a major factor that inhibited the effective management of schools. A lack of adequate resources for teaching could also lead to increased workload for educators. Low teacher satisfaction is expected to correlate with the outcomes of work stress, that is, psychological distress and low self-esteem (Ho \& Au, 2006; Okeke et al., 2014; Gu, 2016; Shumba et al., 2016b). The after-effect of chronic stress is burnout (Cunningham, 1983). Teachers under stress experience feelings of exhaustion, irritability, tension, and headache frequently (Dunham, 1984; Okeke et al., 2014; Adu \& Okeke, 2016).

\section{Forms of Intrinsic Motivators}

Findings in this study confirmed those documented in many studies (e.g., Dinham \& Scott, 1999; 2000a), which noted that the main sources of teacher job satisfaction were the daily satisfaction derived from working with children, aiding their development and seeing them being actively involved in the society whilst making a contribution to the welfare of others. Many expressed the joy of seeing past students in their school establishing 
themselves in the society and earning a good living. A well-oiled education system is important for a number of reasons, including human development and the maintenance of socially responsive economic and political systems (Modisaotsile, 2012). This hints that an educated population remains the fundamental platform for meeting most of the other Millennium Development Goals (MDGs). With the acknowledgement that the youth of today is the ultimate leaders of tomorrow, most governments make significant efforts to invest in their education. It is disheartening to learn that such efforts do not always yield the intended results.

The South African education system is in crisis. This is attested by Modisaotsile (2012), who affirms that there are many indications, such as high enrolment rates and increasingly poor grade 12 output each year. Long-serving teachers also derived high levels of satisfaction when working collaboratively with colleagues and achieving personal professional growth. Teachers being interviewed also confirmed earlier findings that salary, short working hours and holidays were not high in their satisfaction list. According to the teachers' opinions, these were merely associated benefits that made the profession more attractive. All teachers interviewed revealed that their primary source of satisfaction was the children themselves. Many recounted different experiences of 'miracles', which they performed while taking care of their students. These findings confirm the results obtained by Bucknell and Thomas (1996); Muguongo et al. (2015); Wambugu and Busienei (2015); Afshar and Doosti (2016), Mtyuda and Okeke (2016) who contended that satisfaction through working with children, forming relationships with them, having the opportunity to contribute to the growth and achievement of young individuals may be common internationally, regardless of the country and context.

The emotional rewards of teaching affect what teachers teach, the way it is taught and the modalities and curricular adaptations, which they undergo in order to make sure that all students under their care are benefiting from the teaching they are providing. Many teachers spoke about "loving their children", "going out of their way to help them" and "establishing a warm and safe environment in their classrooms". From the interviews, it became clear that long-serving teachers have successfully attempted to develop warm and lasting emotional relationships with students and their parents although some of the parents were not as co-operative as they were not staying with their children throughout the year. Such relationships are so inherent in this work that “...separating myself from such experiences is almost impossible" (participant's statement from FG2).

An area from which teachers appear to derive a sense of self-fulfilment and satisfaction is their contribution to the society. They highlighted the importance of being able to guide students in their life choices and thus effectively contributing to the society. Most teachers emphasised their commitment to the society as an important precept towards their general job satisfaction despite the negative effect that social problems had on their work and the "lack of respect for teachers nowadays". Most teachers felt proud that some of their past students were teachers themselves and that they followed in their own footsteps. In this regard, Warren (2003) claims that what seems to happen to people externally is not as important as their internal emotions. The effect of those internal emotions and thoughts is the most important motivator. People tend to be motivated by different internalised, and often invisible, negative emotions such as guilt, anger, resentment, expectancies, materialism and an overwhelming need for acceptance, appreciation and recognition by others. 


\section{Forms of Extrinsic Motivators}

Most of the teachers interviewed stated that during their career they had some opportunities for professional growth but they would have liked tailor-made courses which took into account their experience. These comments clearly indicate that the teachers' sense of satisfaction is related to intellectual and professional stimulation and also opportunities for growth. As long as teachers are provided with opportunities for innovation, stimulation of their intellectual curiosity and increased creative outputs, they will still be kindling the passion for their profession and further contribute towards students' achievements.

Nevertheless teachers participating in the study highlighted the importance of good salary. Many teachers, in the first part of the study, felt that their salary was rather low compared to the amount of work they performed and the salaries of other professions. This implies that the more the teachers are paid incentives, the better their job satisfaction is. Khan (2003) maintained that teachers with low salaries were more likely to remain in their jobs if the school system provided financial and non-financial incentives to compensate for the salary shortfall. As one teacher from FG2 stated, “...if I am paid for the amount of hours I spend correcting and preparing material for the next day, then my salary will have to be at least double" (her emphasis). Another teacher, however, had a different view about teachers' benefits and stated that for many teachers benefits such as salary, short hours and holidays are important factors when one chooses a profession.

\section{Problems Encountered by Teachers in the Schools}

The study also researched sources of dissatisfaction among school teachers. These were ranked according to the number of times mentioned by the teachers. Students' failure, the effect of social problems, work overload as well as a lack of discipline among students, respect from students and parents, recognition from society, autonomy as a result of perceived centralisation collegial relationships, not to mention time constrictions and extensive syllabi were the factors considered by teachers as contributing to job dissatisfaction. Most teachers recounted that the major source of dissatisfaction lied in the failure of students to achieve the desired academic outcomes. As one teacher emphatically puts it:

\section{I plan, I organise, I approach students as groups and individually, I speak to their parents... but sometimes there are situations that you cannot do away with... there are situations where all your efforts result in nothing... These are, by far, most dissatisfactory.}

Work overload is an expression, which came up often during interviews. Teacher participants seemed to derive particular dissatisfaction with the amount of paper work they did, especially "piles of copybooks", "file keeping”, "printed lesson plans", "schemes of work", "individualised educational plans" and "paperwork, paperwork, paperwork... all the time" (teachers' emphasis). Most teachers commented that while they saw the validity of organising one's work, teaching became "too technical" and "(work overload)... is robbing the joy of teaching”. 
Many social problems were mentioned in the interviews. These included both the teachers' social problems and those of the students. Social problems interfere in communication processes between teachers and students and these have an effect on the performance of both teachers and students in the teaching and learning process. Among those mentioned were the steady rise in family problems, increased number of marital separations and divorces, ill-discipline in the classrooms, poverty and others. During interviews, teachers shared intense feelings of dissatisfaction as a result of having to deal with the effects of social problems in their classrooms. A number of teachers shared the fact that many a time they had to deal with students' lack of resources themselves. As one teacher states:

It is not the first time that I had to deal with pupils who did not have lunch or adequate stationery, especially for me as I am an Accounting teacher. These are the things which everyone takes for granted but they are very much in existence... yes in 2014! There is no recognition whatsoever for the work a teacher does where she/he have to go beyond their duties to make sure a child gets the necessary care. This is very disappointing and de-motivating.

Most of the teachers interviewed insisted that respect towards teachers from both parents and students had diminished. Most comments conveyed the sense of disenchantment resulting from the perceived expectations for respect and recognition which had never been fulfilled through the years. This had given rise to general feelings of dissatisfaction and low morale. The lack of respect and recognition of teachers has been the subject of research in many studies (Demirta, 2010; Basaka \& Ghoshb, 2011; Song \& Alpaslan, 2015; Mtyuda \& Okeke, 2016). The respondents concurred that violent behaviour constituted a definite problem among learners in senior secondary schools, and that bullying was a common problem that needed to be addressed. This general concern about a lack of discipline in classes and schools was also shared by most teachers in all the schools researched. The goals of discipline are to provide a safe environment for all educators, but it is also the responsibility of the learners to show respect and accept discipline from their educators. Hence, these sources of dissatisfaction are not unique to the Education District where the study took place but are present in many countries across the world (Muguongo et al., 2015; Wambugu \& Busienei, 2015; Afshar \& Doosti, 2016).

\section{Aspirations to Become a Teacher}

Research findings indicated that a majority of the respondents were intrinsically motivated; 90 percent of these teachers agreed that they chose the teaching profession because they had passion for teaching. Skaalvik and Skaalvik (2007), Okeke and Dlamini (2013), Dlamini et al. (2014), Afshar and Doosti (2016) found that teachers' self-efficacy influenced their teaching behaviour and their students' motivation and achievement. Self-efficacy is a person's judgment about being able to perform a particular activity. It is a person's I can or I cannot belief (Betoret, 2006). These teachers, irrespective of the unexpected conditions of work they were met with, still expect other teachers to possess the characteristics that are acceptable to the profession. 


\section{Conclusion}

The study concludes that teacher satisfaction is germane for the sustainability of social transformation. In particular, for social transformation to be achieved through the education agency, the satisfaction of teachers must be taken very seriously. The recognition of various contributions teachers are making to a human being and the society at large is germane to teacher job satisfaction. This is because such practice brings about a sense of fulfilment and self-actualisation, and is the driving force that propels the individual teacher to greater performance. This is a crucial factor for teachers because it improves the standards of their teaching.

However, this study found that insufficient support and recognition from the Department of Basic Education (DBE) was a significant source of dissatisfaction and contrary to what teachers expected when they were appointed. The above-mentioned negative views of the teachers concerning the policies and practices of the DBE seemed to have caused disengagement of some teachers, with a consequent lack of focus on professional activities, and being negative and critical about the DBE, parents and learners. This is a cause for concern because disengagement erodes the quality of teaching and learning at schools.

\section{Recommendations}

Based on the findings and conclusions of the study, the researchers recommend that the Department of Basic Education should work out incentive packages to increase teachers' motivation to teach in senior secondary schools. Special attention should be devoted to increasing teachers' salaries because a majority of them (teachers) complained about the inadequacy of their salary to meet their needs. Increasing teachers' salaries will increase their morale to teach. This is because the teachers must be interested in what they teach and in the children when they are teaching. If they are not interested in the work themselves, they can never motivate the class to learn.

The Education District officials, especially subject advisors who help with the teaching and learning at schools need to be developed more through content gap workshops usually organised by the provincial officials so as to be more productive in helping teachers at schools. Regular visits to the schools would motivate the teachers to be more regular and early in school and avoid divided attention of searching for secondary employment.

Awards could be instituted for better performance. Areas such as school and pupil discipline, teacher performance, pupil attendance and achievement, as well as community and parent participation in school activities should be rewarded to serve as motivation.

\section{Limitations of the Study}

The researchers experienced two key limitations in undertaking this study as it was conducted during the time of revision for senior secondary school teachers who were preparing their students for the end of the year examinations. According to the researchers' plan, the transcription was to take only a week. However, the process took longer, the challenge encountered started with the delay in conducting interviews at the requested time due to the writing of examinations and marking of examination scripts. Such limitations may have impacted the quality of the obtained data. 


\section{References}

Adebayo, A.S., \& Gombakomba, T. (2013). Dimensions of teachers' job satisfaction in primary schools in Gweru District, Zimbabwe: A factor analysis. European Scientific Journal, 9(25), 309-317.

Adu, E.A., \& Okeke, C.I.O. (2016). An investigation into the causes of stress among preschool educators in East London Education District. Journal of Psychology, $7(1), 11-22$.

Afshar, H.S., \& Doosti, M. (2016). Investigating the impact of job satisfaction/dissatisfaction on Iranian English teachers' job performance. Iranian Journal of Language Teaching Research, 4(1), 97-115.

Babbie, E.R. (2008). The Practice of Social Research. (11th ed.). Belmont, CA: Wadsworth.

Basaka, R., \& Ghoshb, A. (2011). School environment and locus of control in relation to job satisfaction among school teachers - A study from Indian perspective. Journal of Social and Behavioural Sciences, 29, 1199-1208.

Betoret, F.D. (2006). Stressors, self-efficacy, coping resources, and burnout among secondary school teachers in Spain. Educational Psychology, 26, 519-539.

Bucknell, T., \& Thomas, S. (1996). Critical care nurse satisfaction with levels of involvement in clinical decisions. A Journal of Advanced Nursing, 23(3), 571-577.

Calitz, T., Roux, A., \& Strydom, H. (2014). Factors that affect social workers' job satisfaction, stress and burnout. Social Work, 50(2), 153-169.

Chan, D.W. (2002). Stress, self-efficacy, social support, and psychological distress among prospective Chinese teachers in Hong Kong. Educational Psychology, 22(5), 557569.

Creswell, J.W. (2014). Research Design: Qualitative, Quantitative, and Mixed Methods Approaches (4th Ed.). New York: Sage Publications.

Cunningham, W.G. (1983). Teacher burnout-solution for the 1980's: A review of the literature. Urban Review, 15, 37-51.

Demirta, Z. (2010). Teachers' job satisfaction levels. Journal of Social and Behavioural Sciences, 9, 1069-1073.

Department of Education. (2005). Enabling Safe and Effective Teaching and Learning Environment: A Resource Book. Pretoria, SA: Department of Education.

Dinham, S., \& Scott, C. (1999). The occupational motivation, satisfaction and health of English school teachers. Educational Psychology, 19(3), 287-308.

Dinham, S., \& Scott, C. (2000). Moving into the third, outer domain of teacher satisfaction. Journal of Educational Administration, 38(4), 379-96.

Dlamini, S.C., Okeke, C.I.O., \& Mammen, K.J. (2014). An investigation of workrelated stress among high school teachers in the Hhohho region of Swaziland. Mediterranean Journal of Social Sciences, 5(15), 575-586.

Dunham, J. (1984). Stress in Teaching. London: Croom Helm.

Farrell, J.P. (2000). Teaching the Developing Countries. The World Bank. Washington, D.C.

French. L., \& Wagner, B. (2010). Motivation, work satisfaction, and teacher change among early childhood teachers. Journal of Research in Childhood Education, 24(2), 152-171.

Gkolia, A., Belias, D., \& Koustelios, A. (2014). Teacher's job satisfaction and selfefficacy: A review. European Scientific Journal, 10(22), 321-342. 
$\mathrm{Gu}, \mathrm{X}$. (2016). Teacher job satisfaction in public schools: The relation to the years of teaching experience. Unpublished master's dissertation. New York: State University of New York.

Ho, C.L., \& Au, W.T. (2006). Teaching satisfaction scale: Measuring job satisfaction of teachers. Educational and Psychological Measurement, 66, 172-185.

Iwu, C.G., \& Iwu, I.C. (2013). Factors inhibiting effective management of primary schools in Nigeria: The case of Ebonyi State. Journal of Social Sciences, 35(1), 51-60.

Jonane, L. (2015). Using analogies in teaching physics: A study on Latvian teachers' views and experience. Journal of Teacher Education for Sustainability, 17(2), 53-73.

Khan, T. (2003). Teacher Job Satisfaction and Incentive: A Case Study of Pakistan. Retrieved 16 August 2016, from http://datatopics.worldbank.org/hnp/files/edstats/ PAKstu06a.pdf

Lukk, K., Veisson, M., \& Ots, L. (2008). Characteristics of sustainable changes for schools. Journal of Teacher Education for Sustainability, 9, 35-44.

MacMillan, J.H., \& Schumacher, S. (2010). Research in Education: Evidence-Based Inquiry (7th Ed.). Boston: Pearson Publishers.

Masitsa, G. (2004). Four critical causes of under-achievement in township secondary schools. Acta Academica, 36(1), 213-245.

Maslow, A.H. (1954). Motivation and personality. Psychological Review, 50, 370-396.

Modisaotsile, B.R. (2012). The Failing Standard of Basic Education in South Africa. Pretoria, SA: Africa Institute of South Africa.

Mtyuda, P.N.P., \& Okeke, C.I.O. (2016). Factors associated with teachers' job dissatisfaction in schools in rural Eastern Cape Province. Studies of Tribes \& Tribal (S-T \& T), 14(1), 44-53.

Muguongo, M.M., Muguna, A.T., \& Muriithi, D.K. (2015). Effects of compensation on job satisfaction among secondary school teachers in Maara Sub-County of Tharaka Nithi County, Kenya. Journal of Human Resource Management, 3(6), 47-59.

Naseem, I., \& Salman, M. (2015). Measuring the job satisfaction level of the academic staff. Journal of Business \& Financial Affairs, 4(2), 1-6.

Okeke, C.I.O. (2010). Gender and Schooling: A Qualitative Study of Teens' Perception of Schooling in a Nigerian Suburb. Germany: VDM Verlag Dr Muller.

Okeke, C.I.O., Adu, E.O., Drake, M.L., \& Duku, N.S. (2014). Correlating demographic variables with occupational stress and coping strategies of pre-school educators: A literature review. Journal of Psychology, 5(2), 143-154.

Okeke, C.I.O., \& Dlamini, S.C. (2013). An empirical study of stressors that impinge on teachers in secondary school in Swaziland. South African Journal of Education, 33(1), 32-43.

Peretomode, V.F. (1991). Educational Administration, Applied Concepts and Theoretical Perspectives for Students and Practitioners. Lagos: JOJA Educational Research and Publishers Limited.

Perrachione, B.A., Rosser, V.J., \& Petersen, G.J. (2008). Why do they stay? Elementary teachers' perceptions of job satisfaction and retention. The Professional Educator, $32(2), 25-41$.

Shumba, J., Maphosa, C., Rembe, S., Okeke, C.I.O., \& Drake, M.L. (2016b). Teacher work related stress in early childhood education: Some coping strategies. Journal of Psychology, 7(2), 150-158. 
Skaalvik, E.M., \& Skaalvik, S. (2007). Dimensions of teacher self-efficacy and relations with strain factors, perceived collective teacher efficacy, and teacher burnout. Journal of Educational Psychology, 99, 611-625.

Smith, P.C. (2002). In pursuit of happiness: Why study general job satisfaction? In C.J. Cranny, P.C. Smith, \& E.F. Stone (Eds.), Job satisfaction (pp. 5-19). New York: Lexington Books.

Song, S.C., \& Alpaslan, M.M. (2015). Factors impacting on teachers' job satisfaction related to science teaching: A mixed methods study. Science Education International, 26(3), 361-378.

Spector, P.E. (2008). Job Satisfaction: Applications, Assessment, Causes, and Consequences. Thousand Oaks, CA: Sage.

Taylor-Powell, E., \& Renner, M. (2003). Analysing Qualitative Data. Wisconsin, USA: University of Wisconsin.

Tillmanns, T., Holland, C., Lorenzi, F., \& McDonagh, P. (2014). Interplay of rhizome and education for sustainable development. Journal of Teacher Education for Sustainability, 16(2), 5-17.

van der Westhuizen, C.N. (2004). The games institutions play - or the impact of university incorporation on the attitude, beliefs and perceptions of college lecturers. Social and Behavioural Science, 33, 563-56.

van Houtte, M. (2006). Tracking and teacher satisfaction: Role of study culture and trust. Journal of Educational Research, 99(4), 247-254.

Wambugu, T.W., \& Busienei, J.R. (2015). Factors leading to job satisfaction of public secondary school teachers in Nairobi County, Kenya. The Strategic Journal of Business \& Change Management, 2(122), 1988-2008.

Warren, R. (2003). Die Doelgerigte Lewe. Jeppestown, SA: Zondervan ZA.

Wensing, E.J., \& Torre, C.A. (2009). The ecology of education: Knowledge systems for sustainable development and sustainability. Journal of Teacher Education for Sustainability, 11(1), 3-17.

Correspondence concerning this paper should be addressed to Professor Chinedu Okeke, Faculty of Education, University of Fort Hare, East London Campus, 50 Church Street, East London 5200, South Africa. Email: COkeke@ufh.ac.za 